\title{
Analysis of a Benthic Community Food Web Using Isotopically Labelled Potential Food
}

\author{
M. H. Beviss-Challinor and J. G. Field \\ Zoology Department, University of Cape Town, Rondebosch 7700, South Africa
}

\begin{abstract}
A series of experiments was designed to reveal the trophic structure of a benthic community using kelp holdfasts as microcosms within the kelp-bed community. The experimental food comprised zooplankton represented by ${ }^{3} \mathrm{H}_{2} \mathrm{O}$-labelled Artemia sp. eggs and nauplii (200 to $300 \mu \mathrm{m}$ ). detritus derived from ${ }^{14} \mathrm{C}$-labelled kelp $(60$ to $90 \mu \mathrm{m})$, and phytoplankton represented by ${ }^{14} \mathrm{C}$-labelled Dunaliella primolecta $(5$ to $10 \mu \mathrm{m})$ cultures. Separate experiments of short duration ( 1 to $2 \mathrm{~h}$ ) were used to indicate the primary consumers on each type of food, while longer experiments (4, 8 and $16 \mathrm{~h}$ ) suggested the secondary consumers (coprophagous and carnivorous species). Several species were found to be omnivorous
\end{abstract}

\section{INTRODUCTION}

The greatest single lack of knowledge in biological oceanography is that of fluxes in marine ecosystems (Mann, 1982). The most common fluxes in biological systems are the trophic transfers, yet the question of who eats whom in the marine environment is often very difficult to solve. Three methods have been widely used to date, i.e. gut content analysis (e.g. Roger and Grandperrin, 1976); direct observation (Gilmer, 1972; Hamner et al., 1975; Alldredge, 1976) and experimental exclusion of the prey or food (Gerlach et al., 1976). The classical method of gut content analysis is often tedious, biased by differential digestion rates and extremely labour intensive (Smith, 1982). Visual observation and exclusion of prey species or supply of food may often be impossible when species are too small. In a recent paper, Smith et al. (1979) describe a method of in situ food web analysis using natural food items radiolabelled with ${ }^{14} \mathrm{C}$ or ${ }^{3} \mathrm{H}$. They were able to map a portion of a food web involving microscopic organisms such as demersal zooplankton. In this paper we describe a similar method of radioactively labelling potential food and subsequently tracing it down a food chain. Three potential food sources are available from the water column to the benthic community: phytoplankton, zooplankton and detritus. These were used in separate experiments.

\section{METHODS}

Holdfasts of the giant kelp Ecklonia maxima Osbeck were obtained from Oudekraal off the West coast of the Cape Peninsula, South Africa ( $\left.34^{\circ} 00^{\prime} \mathrm{S} / 18^{\circ} 21^{\prime} \mathrm{E}\right)$. The holdfasts were removed from the substrate by SCUBA diving with minimal disturbance to the animals living amongst the kelp haptera. The whole holdfast was immediately placed in a plastic bag underwater to prevent escape of the mobile animals and transported to the laboratory. There it was held overnight in an aquarium at $12^{\circ} \mathrm{C}$ to allow the community to settle and resume feeding (noted by opening of the valves of the ribbed mussel Aulacomya ater Molina). A magnetic stirrer circulated the water around the holdfast which was kept off the bottom of the $10 \mathrm{l}$ aquarium tank by a plastic mesh. All feeding experiments were conducted within $24 \mathrm{~h}$ to minimise stress on the animals.

Three potential foods were labelled and used in separate experiments: phytoplankton, zooplankton and detritus. The experiments with phytoplankton and zooplankton were primarily aimed at detecting which members of the benthic community fed on these items. The experiments on detritus had the additional aim of tracing the food chain further, to detect which animals might feed on faeces of the suspension feeders or prey upon the suspension feeders themselves. To this end, 5 experiments of $1,2,4,8$ and $16 \mathrm{~h}$ duration were performed. 
In the experiments, cultures of Dunaliella primolecta were used to represent phytoplankton (diameter ca $8 \mu \mathrm{m})$, eggs and nauplii of Artemia sp. conveniently represented zooplankton (200 to $300 \mu \mathrm{m}$ ), and powdered kelp (particles 60 to $90 \mu \mathrm{m}$ ) represented detritus. Details of their preparation are given below.

\section{Zooplankton}

Artemia sp. eggs and nauplii were selected to represent zooplankton because they are easily cultured. They were labelled by adding $300 \mu \mathrm{Ci}$ of ${ }^{3} \mathrm{H}_{2} \mathrm{O}$ to $1.5 \mathrm{l}$ fresh seawater and sprinkling fresh Artemia eggs over the surface. Air was bubbled slowly through the medium to maintain the potential food in suspension and the temperature was kept at $20^{\circ} \mathrm{C}$. After $2 \mathrm{~d}$ the hatched nauplii and unhatched eggs were used together in a single feeding experiment. Before addition to the aquarium, the Artemia were rinsed by filtering through glass wool and pouring triplicate amounts of $200 \mathrm{mll}$ fresh seawater over the eggs and nauplii. They were then resuspended in $1 \mathrm{l}$ of seawater and added to the aquarium held at $12^{\circ} \mathrm{C}$. Some were retained, diluted similarly, and their leaching rate determined. Two $5 \mathrm{ml}$ samples were taken every $30 \mathrm{~min}$ for $2 \mathrm{~h}$ and filtered through $3 \mu \mathrm{m}$ membranes which were frozen until solubilised. A second detailed leaching experiment was conducted, sampling nauplii and eggs incubated for eight days every 15 min for $2 \mathrm{~h}$, although these were not used in a feeding experiment.

\section{Phytoplankton}

Cultures of Dunaliella primolecta were grown for 3 to $5 \mathrm{~d}$ at $14{ }^{\circ} \mathrm{C}$ in Walnes medium with $\mathrm{NaH}^{14} \mathrm{CO}_{3}$ at a concentration of $200 \mu \mathrm{Ci} \mathrm{l}^{-1}$. Light was supplied by three double banks of $20 \mathrm{~W}$ fluorescent lights (Agrolite) at approximately $10 \mathrm{~cm}$ distance from the flask with a combined intensity of $190 \mu \mathrm{Em}^{-2} \mathrm{~s}^{-1}$. The cultures were agitated by a magnetic stirrer. The cultures of approximately $10 \times 10$ cells $1^{-1}$ were diluted approximately 10 times when added to the $10 \mathrm{l}$ tank giving a concentration of particulate matter similar to that measured in kelp beds (Field et al., 1980b) and giving optimal filtration rates of Aulacomya ater (Griffiths and King, 1979), the major faunal component of the kelp holdfast.

Label which had not been taken up by the algae was discarded to ensure that label in the consumers originated from food and was not absorbed from the water. Rinsing the Dunaliella primolecta cultures involved repeatedly centrifuging the cells, pouring off the supernatant and resuspending the algae in fresh 0.45 um membrane filtered seawater. Samples were centrifuged for $10 \mathrm{~min}$ at $2000 \mathrm{rpm}$, a slow speed being used to avoid cell rupture. After 3 rinsings the algae were added to the tank holding the experimental holdfast, and the dilution factor noted. A subsample of this stock was retained and diluted similarly in a beaker and held under the same temperature and light conditions to test the rate of leaching of ${ }^{14} \mathrm{C}$ from the algae during the experiment. Two aliquots of $100 \mathrm{ml}$ each were taken at $0,30,60,90$ and $120 \mathrm{~min}$ after the start of the experiment. These were vacuum filtered $(0.05 \mathrm{~mm}$ $\mathrm{Hg}$ ) through $3 \mu \mathrm{m}$ Nuclepore polycarbonate membrane filters and frozen at $-12{ }^{\circ} \mathrm{C}$ until solubilised with soluene and treated for liquid scintillation counting (see below).

\section{Detritus}

Young Laminaria pallida plants (approx. $75 \mathrm{~cm}$ long) were collected at Oudekraal, off the west coast of the Cape Peninsula from a depth of $10 \mathrm{~m}$ and placed individually in three $9 \mathrm{l}$ perspex cylinders. Fresh 0.2 $\mu \mathrm{m}$ filtered seawater plus $300 \mu \mathrm{Ci}, \mathrm{NaH}^{14} \mathrm{CO}_{3}$ was added to each cylinder. Light was supplied by 3 double banks of $20 \mathrm{~W}$ fluorescent lights at $10 \mathrm{~cm}$ distance with a combined light intensity of $190 \mu \mathrm{Em}^{-2} \mathrm{~S}^{-1}$. Temperature was held constant at $12{ }^{\circ} \mathrm{C}$ and water circulated using simple water pumps.

After 2 to $3 \mathrm{wk}$ incubation the kelp plants were thoroughly rinsed, freeze-dried and milled. This artificial detritus was then size-fractioned into 5 classes. Detritus in the size range 60 to $90 \mu \mathrm{m}$ was used in the experiments, primarily because this fraction contained the most detritus. In the short experiments $(1,2$ and $4 \mathrm{~h})$ $400 \mathrm{mg}$ detritus (dry mass) were aged for $90 \mathrm{~h}$ in $250 \mathrm{ml}$ fresh seawater collected from Oudekraal. Detritus was prepared for the 8 and $16 \mathrm{~h}$ experiments by aging 800 $\mathrm{mg}$ for $18 \mathrm{~h}$ in $250 \mathrm{ml}$ seawater. Ageing the detritus allowed bacteria to colonise the particles (Stuart et al., 1981).

Detritus was rinsed similarly to phytoplankton although a much faster centrifuge speed of $14000 \mathrm{rpm}$ was used. After 3 rinsings the detritus was resuspended in $250 \mathrm{ml}$ seawater and added to the tank, or in the 8 and $16 \mathrm{~h}$ experiments $210 \mathrm{ml}$ detritus suspension was added over $1 \mathrm{~h}, 30 \mathrm{ml}$ every $10 \mathrm{~min}$. This was done to minimise settling of the heavy detrital load so that the food was kept in suspension for the filter feeders. The leaching rate of ${ }^{14} \mathrm{C}$ from the detritus was measured. After $14 \mathrm{~h}$ ageing in fresh seawater and rinsing as described above, duplicate $1 \mathrm{ml}$ samples were taken every hour for the first $4 \mathrm{~h}$, then at 8,12 and $16 \mathrm{~h}$ after the start. These were filtered through $0.2 \mu \mathrm{m}$ membranes and then treated for liquid scintillation counting as described below. 


\section{Treatment of Samples}

After the allocated time period the holdfast was removed from the experimental vessel, rinsed in dilute $(5 \%) \mathrm{HCl}$ and again in fresh seawater to remove any adhering labelled material. It was then frozen to kill the fauna and once thawed, the holdfast was dissected to remove the animals. The specimens were identified, washed, placed in glass vials and freeze dried for 48 to $72 \mathrm{~h}$. Once dry they were milled in a WIG-L-BUG (Crescent Dental Co., Chicago) or simply crushed in the vial using a glass rod. Homogenised sub-samples were weighed on a Mettler ME-30 microbalance to the nearest $0.01 \mathrm{mg}$ and placed in clean glass scintillation vials. Samples of between 5 and $20 \mathrm{mg}$ were used where possible.

Animals from the holdfast to which tritiated Artemia eggs and nauplii had been added were not dried since this would have resulted in the loss of ${ }^{3} \mathrm{H}_{2} \mathrm{O}$ from the samples. Thus they were weighed wet and these values were later converted to dry mass using wet-dry mass ratios given by Field et al. (1980a).

Soluene-350 (Packard), a tissue solubilizer containing $0.5 \mathrm{M}$ quarternary ammonium hydroxide in toluene, was used to solubilize the samples. Dry animal tissue was dissolved within $24 \mathrm{~h}$ at $55^{\circ} \mathrm{C}$ by the addition of $0.1 \mathrm{ml} \mathrm{H}_{2} \mathrm{O}$ and $1.0 \mathrm{ml}$ Soluene. Samples from the leaching experiments were solubilized similarly. The wet animal samples from the tritium experiment required $1.5 \mathrm{ml}$ Soluene to achieve complete solubilization. After $24 \mathrm{~h}$ the samples were treated with $0.5 \mathrm{ml}$ isopropanol and $0.2 \mathrm{ml} \mathrm{H}_{2} \mathrm{O}_{2}$ to reduce colour quenching. Wet samples required an additional $0.1 \mathrm{ml} \mathrm{H}_{2} \mathrm{O}_{2}$ to complete the bleaching. After further 12 $\mathrm{h}$ incubation at $55^{\circ} \mathrm{C}$ the vials were allowed to cool and then $10 \mathrm{ml}$ Dimilume-30 (Packard) scintillation cocktail was added. The vials were sealed, shaken to ensure complete mixing and allowed to settle for $12 \mathrm{~h}$ before being placed in a liquid scintillation spectrometer (Packard Instruments, Model 3885). After 30 min dark adaption, the samples were counted for $10 \mathrm{~min}$ each. The data were then converted to disintegrations per minute (dpm), using a previously constructed quench curve obtained by repeatedly adding $50 \mathrm{ml}$ solubilised mussel tissue to a standard of known activity.

\section{RESULTS}

\section{Isotope Uptake and Leaching from Food}

Tritium uptake by Artemia sp. was only $0.016 \%$ and $0.067 \%$ after 2 and $8 \mathrm{~d}$ incubation respectively. The poor uptake may be attributed to three factors: (1) the large dilution of ${ }^{3} \mathrm{H}_{2} \mathrm{O}$ in sea water, which necessitates very high dosage of the radio-isotope (McKinley and Wetzel, 1977; Smith et al., 1979); (2) isotopic discrimination due to the large mass ratio of tritium to hydrogen in water molecules (McKinley and Wetzel, 1977); and (3) the passive nature of $\mathrm{H}_{2} \mathrm{O}$ uptake in aquatic organisms, compared to active carbon uptake in photosynthesis. Fig. 1 shows that tritium leaches out of the

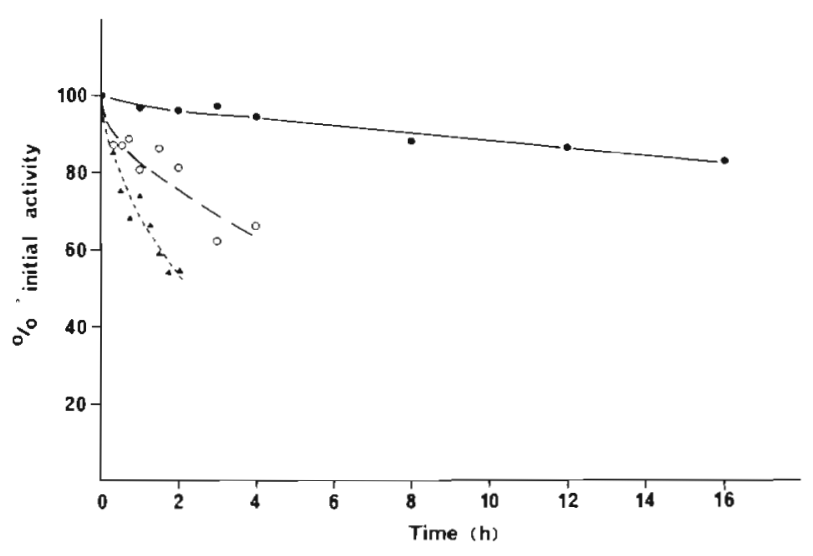

Fig. 1. Leaching curves depicting the loss of radioisotope from labelled potential food rinsed with fresh seawater after soaking for different periods. Artemia sp. eggs and nauplii, incubated in ${ }^{3} \mathrm{H}_{2} \mathrm{O}$ for $8 \mathrm{~d}$ (triangles); Dunaliella primolecta incubated with $\mathrm{NaH}^{14} \mathrm{CO}_{3}$ for $4 \mathrm{~d}$ (open circles); Laminaria pallida, incubated with $\mathrm{NaH}^{14} \mathrm{CO}_{3}$ for $20 \mathrm{~d}$, freeze-dried and ground to 60 to $90 \mu \mathrm{m}$ artificial detritus particles and soaked for $90 \mathrm{~h}$ before leaching experiment (closed circles). Exponential curves fitted by least squares

Artemia eggs and larvae rapidly and exponentially. The rate of loss appears to be affected by incubation time: Smith et al. (1979) noted $80 \%$ loss in $2 \mathrm{~h}$ after incubating Oithona oculata for $15 \mathrm{~min}$ (at high tritium concentrations of $1 \mathrm{Ci}$ per $10 \mathrm{ml}$ ) whereas the present experiments showed $69 \%$ and $46 \%$ declines in activity in $2 \mathrm{~h}$ after incubating for 2 and $8 \mathrm{~d}$ respectively. It appears that after prolonged incubation, more ${ }^{3} \mathrm{H}$ is incorporated in molecules other than free water. Nevertheless, the rapid leaching rate and large tritium doses required, preclude the use of tritium in any prolonged experiment.

Dunaliella primolecta incubated with $\mathrm{NaH}{ }^{14} \mathrm{CO}_{3}$ absorbed $2.73 \%$ and $0.72 \%$ of the isotope in the 2 experimental media respectively. The leaching experiment (Fig. 1) shows that, after rinsing, ${ }^{14} \mathrm{C}$ leaches out, declining by $35 \%$ in $4 \mathrm{~h}$.

Artificial detritus prepared from the kelp Laminaria pallida had initial counts of $3700 \mathrm{dpm} \mathrm{ml}-1$ which dropped by $17 \%$ to some $3000 \mathrm{dpm} \mathrm{m}^{-1}$ over $16 \mathrm{~h}$ (Fig. 1). Thus the algal culture and detritus are stably labelled with ${ }^{14} \mathrm{C}$ which leaches out slowly, and are therefore suitable for experiments of longer duration than the tritiated zooplankton. 


\section{Feeding Experiments}

The experiment in which a kelp holdfast community was exposed to tritium-labelled Artemia eggs and nauplii as food was only partially conclusive because of the low level of activity in the Artemia. In order to judge which animals had fed on the labelled food, it is necessary to use an arbitrary threshold value below which radioactivity is likely to have been caused by background activity or by material released by the labelled food (Smith et al., 1979). We have taken this value to be $100 \mathrm{dpm} \mathrm{mg}^{-1}$ (dry mass) of animal. According to this criterion, of the 22 species in the experimental community only Ceradocus rubromaculatus (Stimpson), a gammarid amphipod whose trophic position is listed as uncertain by Day (1974), clearly took up the labelled zooplankton (Table 1). In the remaining species the activity may have been due to leaching of ${ }^{3} \mathrm{H}_{2} \mathrm{O}$ from adhering particles before washing or other such factors. In a short 2 -h experiment of this nature, negative results are inconclusive because of varying feeding behaviour: specimens may not have fed during the experiment.

The results of exposing 2 experimental kelp holdfast communities to ${ }^{14} \mathrm{C}$-labelled phytoplankton cells (5 to $10 \mu \mathrm{m}$ diameter) are given in Table 2. Because of the higher specific activity of the potential food when compared to ${ }^{3} \mathrm{H}$-labelled Artemia, a higher arbitrary threshold of $250 \mathrm{dpm} \mathrm{mg}^{-1}$ (dry mass) ${ }^{-1}$ was chosen to separate animals deemed to have fed on Dunaliella primolecta from those contaminated.

The wellknown filter feeding ribbed mussel Aulacomya ater and the rarer black mussel Choromytilus meridionalis head the list, the Iower specific activity of the latter being attributed to the large size and delayed feeding response of the solitary specimen. Four amphipods and 1 ophiuroid species all show high specific activities indicating that they ingested the phytoplankton during the 2-h experiments; none of these were known to be phytoplankton feeders and it seems likely that the amphipods, which do not have filtering setae, may pick out clumps of cells. Our arbitrary threshold includes as phytoplankton feeders Bryozod and another known filter feeder, the polychaete Gunnarea capensis. No known carnivore exceeded our threshold, and the deposit-feeding polychaetes Notomastus latericeus and Cirriformia capensis were well below the threshold, as were the 8 specimens of the holothurian Pentacta doliolum which, being a dendrochirotid, one might have expected to be a suspension feeder. There is no suggestion of filter feeding amongst the starfish, although Carefoot (1977) reports that Henricia laeviuscula from the Pacific Ocean is a filter feeder. The results therefore are consistent with known information and add some new observations on phytoplankton-feeding.

Table 1. Radioactivity of microcosm animals after $2 \mathrm{~h}$ exposure to ${ }^{3} \mathrm{H}$-labelled Artemia sp. eggs and nauplii as potential food. Trophic categories, after Day (1974) are: F filter feeder, C carnivore, O omnivore, D deposit feeder

\begin{tabular}{|c|c|c|c|c|}
\hline Species/Group & $\begin{array}{l}\text { Taxonomic } \\
\text { group }\end{array}$ & $\begin{array}{l}\text { Trophic } \\
\text { position }\end{array}$ & $\begin{array}{l}\mathrm{dpm}_{\mathrm{mg}}^{-1} \\
\text { (dry mass) }\end{array}$ & $\begin{array}{l}\text { No. in sample } \\
\text { (n) }\end{array}$ \\
\hline Ceradocus rubromaculatus & Amphipod & $?$ & 199.3 & $(2)$ \\
\hline Aulacomya ater & Bivalve & $F$ & 68.6 & (10) \\
\hline Cirriformia capensis & Polychaete & $\mathrm{D}$ & 65.5 & $(2)$ \\
\hline Maera hambigera & Amphipod & $?$ & 64.5 & (2) \\
\hline Sipunculida & & $\mathrm{D}$ & 32.5 & (1) \\
\hline Synalpheus anisocheir & Decapod & $\mathrm{C}$ & 29.3 & (1) \\
\hline Pentacta doliolum & Holothuroid & $?$ & 26.0 & (4) \\
\hline Pherusa laevis & Polychaete & $\mathrm{D}$ & 25.0 & (1) \\
\hline Anthothoe stimpsoni & Anemone & C & 21.7 & (1) \\
\hline $\begin{array}{l}\text { Platyhelminthes } \\
\text { (Species A) }\end{array}$ & & $?$ & 17.9 & (1) \\
\hline Cymodoce unguiculata & Isopod & $?$ & 17.5 & (2) \\
\hline Plagusia chabrus & Decapod & $\mathrm{C}$ & 17.3 & (1) \\
\hline Lepidonotus semitectus & Polychaete & $\mathrm{C}$ & 15.3 & (4) \\
\hline Cirolana sulcata & Isopod & $?$ & 15.0 & (4) \\
\hline Euphrosine capensis & Polychaete & $\mathrm{C}$ & 14.9 & (2) \\
\hline Arabella iricolor & Polychaete & $\mathrm{C}$ & 13.4 & (3) \\
\hline Dendronereis arborifera & Polycaete & 0 & 12.9 & (3) \\
\hline Platyhelminthes & & & & \\
\hline (Species B) & & $?$ & 9.6 & (1) \\
\hline Burnupena papyracea & Gastropod & $?$ & 9.5 & (1) \\
\hline Ophiothrix fragilis & Ophiuroid & $?$ & 8.7 & (4) \\
\hline Annametra occidentalis & Crinoid & $F$ & 5.6 & (1) \\
\hline Parechinus angulosus & Echinoid & 0 & 3.1 & (2) \\
\hline
\end{tabular}


Table 2. Radioactivity of microcosm animals after 2 -h exposure to ${ }^{14} \mathrm{C}$-labelled Dunaliella primolecta in 2 feeding experiments Numbers of experimental animals in parentheses. Trophic categories, after Day (1974) are: F filter feeder, C carnivore O omnivore, D deposit feeder. Horizontal dashed line: arbitrary threshold level of $250 \mathrm{dpm} \mathrm{mg}^{-1}$ (dry mass). See text for details

\begin{tabular}{|c|c|c|c|c|c|c|}
\hline Species & $\begin{array}{c}\text { Taxonomic } \\
\text { group }\end{array}$ & $\begin{array}{l}\text { Trophic } \\
\text { position }\end{array}$ & \multicolumn{2}{|c|}{$\begin{array}{ll}\text { Experiment } 1 \\
{\text { dpm } \mathrm{mg}^{-1}}^{(\mathrm{n})}\end{array}$} & \multicolumn{2}{|c|}{$\begin{array}{cl}\text { Experiment } & 2 \\
{\text { dpm } m g^{-1}}^{(n)}\end{array}$} \\
\hline Aulacomya ater & Bivalve & $F$ & 7468 & (17) & 109068 & (14) \\
\hline Choromytilus meridionalis & Bivalve & F & - & - & 9130 & (1) \\
\hline Maera inaequipes & Amphipod & $?$ & 2844 & (1) & 1733 & (1) \\
\hline Ceradocus rubromaculatus & Amphipod & $?$ & 392 & $(2)$ & - & (1) \\
\hline Ophiothrix fragilis & Ophiuroid & $?$ & 963.3 & (2) & 260 & (1) \\
\hline Temnophlias capensis & Amphipod & $?$ & 662.0 & (1) & - & \\
\hline Bryozoa & & $\mathrm{F}$ & 537.4 & (1) & - & \\
\hline Gunnarea capensis & Polychaete & F & - & & 394 & (3) \\
\hline Maera vagans & Amphipod & $?$ & 385.6 & (3) & - & \\
\hline Euphrosine capensis & Polychaete & C & 219.8 & (2) & - & \\
\hline Arabella iricolor & Polychaete & C & - & & 200 & (1) \\
\hline Hyale grandicornis & Amphipod & $?$ & - & & 178 & (1) \\
\hline Lepidonotus semitectus & Polychaete & $\mathrm{C}$ & 154.2 & (8) & 178 & (1) \\
\hline Eulalia capensis & Polychaete & $\mathrm{C}$ & 75.7 & (2) & - & \\
\hline Trypanosyllis gemmulifera & Polychaete & $\mathrm{C}$ & 60.6 & (1) & - & \\
\hline Pentacta doliolum & Holothuroid & $?$ & 64.4 & (8) & - & \\
\hline Eunice aphroditois & Polychaete & $\mathrm{C}$ & 55.2 & (2) & 141 & (2) \\
\hline Notomastus latericeus & Polychaete & $\mathrm{D}$ & - & & 122 & (1) \\
\hline Pseudonereis variegata & Polychaete & $\mathrm{O}$ & 46.7 & (1) & 56 & (1) \\
\hline Cirriformia capensis & Polychaete & $\mathrm{D}$ & - & & 86 & (1) \\
\hline Arabella iricolor & Polychaete & C & 46.2 & (4) & - & \\
\hline Lumbrineris coccinea & Polychaete & $?$ & 40.1 & (1) & - & \\
\hline Patiria granifera & Asteroid & $?$ & 36.3 & (2) & - & \\
\hline Synalpheus anisocheir & Decapod & C & 34.4 & (2) & - & \\
\hline Anthothoe stimpsoni & Anemone & $\mathrm{C}$ & 33.8 & (1) & - & \\
\hline Nereis sp. & Polychaete & $\mathrm{C}$ & - & & 31 & (1) \\
\hline Henricia ornata & Asteroid & $?$ & 26.6 & (4) & - & \\
\hline
\end{tabular}

Table 3 presents results of a series of experiments of increasing duration. In these, holdfast community microcosms were exposed to artificial detritus in the size range 60 to $90 \mu \mathrm{m}$, obtained by grinding ${ }^{14} \mathrm{C}$-labelled kelp. Results in these experiments have been corrected for background activity, hence the threshold can be set much lower. Taking a threshold value of $10 \mathrm{dpm} \mathrm{mg}^{-1}$ in the 1 -h and 2-h experiments to indicate direct uptake of the detritus, several species emerge as suspected detritus feeders: the amphipods Ceradocus rubromaculatus and Maera inaequipes, the polychaetes Euphrosine capensis, Gunnarea capensis and possibly Trypannosyllis gemmulifera and the brittle star Ophiothrix fragilis which forms dense beds in some kelp-community areas. C. rubromaculatus is the only species which gave a positive indication of feeding in all 3 series of experiments on zooplankton, phytoplankton and detritus respectively, while $M$. inaequipes, $G$. capensis and $O$. fragilis all responded positively to both phytoplankton and detritus.

In experiments of longer duration, radioactive label may be passed along food chains through coprophagy or through predation on detritus-feeders. Quantitative comparisons between experiments are complicated by variations in label and food concentrations, so results in Fig. 2 have been expressed as percentages of the total activity measured in each experiment. Several species were sampled in all or nearly all experiments. Ophiothrix fragilis, Maera inaequipes and the Bryozoa all show evidence of detritus-feeding activity in the shorter experiments, with slight declines relative to the other fauna in longer experiments, confirming their status as detritus feeders (Fig. 2). The polychaetes Euphrosine capensis, Eulalia capensis and Lepidonotus semitectus show relative increases in activity after the longer experiments as does the isopod Cymodoce unquiculata (Fig. 2). These are all believed to be carnivorous because of their jaw morphology (Day, 1967, 1974); since they are unlikely to be coprophagous, our results provide confirmation. Unfortunately, few tentacle-feeding species were sampled in the microcosms, but both the polychaetes Cirriformia capensis and Pherusa sp., listed by Day (1974) as deposit feeders, show greater or high levels of radioactivity in the prolonged experiments (Table 3), suggesting that they feed coprophagously or possibly on settled detritus in spite of vigorous stirring designed to keep the added material in suspension. 
Table 3. Radio-acitivity of animals after exposing kelp-holdfast communities to ${ }^{14} \mathrm{C}$-labelled kelp detritus (60 to $\left.90 \mu \mathrm{m}\right)$ in experiments of different duration. Asterisks: species averaging more than an arbitrary $10 \mathrm{dpm} \mathrm{mg}^{-1}$ in 1 - $\mathrm{h}$ and 2-h experiments, suggesting that they fed directly on the detritus. Trophic abbreviations are based on Day (1974); C carnivore, D deposit feeder, F filter feeder, G grazer, O omnivore

\begin{tabular}{|c|c|c|c|c|c|c|}
\hline \multirow[t]{2}{*}{ Species/Group } & \multirow{2}{*}{$\begin{array}{l}\text { Trophic } \\
\text { category }\end{array}$} & \multicolumn{5}{|c|}{ dpm $\mathrm{mg}^{-1}$ (dry mass) } \\
\hline & & 1-h expt. & 2-h expt. & $4-\mathrm{h}$ expt. & 8-h expt. & 16-h expt. \\
\hline Anthozoa & ? & & 3.1 & & & \\
\hline Arabella iricolor & $\mathrm{C}$ & 0.1 & & 4.0 & & \\
\hline Aulacomya ater & $\mathrm{F}$ & 5.3 & 2.1 & 7.7 & 0.8 & 5.1 \\
\hline Bryozoa & $F$ & 4.8 & 6.1 & & 19.6 & 6.3 \\
\hline Ceradocus rubromaculatus & $?$ & 34.2 & & & & 45.3 \\
\hline Cirolana sulcata & $?$ & 4.2 & 1.7 & & 8.6 & \\
\hline Cirriformia capensis & $\mathrm{D}$ & 2.9 & & & 10.1 & \\
\hline Corynactis annulata & $\mathrm{C}$ & 7.3 & & & 0.8 & 13.4 \\
\hline Cymodoce unguiculata & ? & 2.2 & 1.8 & 13.9 & 26.7 & 60.8 \\
\hline Dromidia unidentata & $\mathrm{C}$ & & 5.9 & 13.3 & & \\
\hline Eulalia capensis & C & & 0.7 & & 8.4 & 14.9 \\
\hline Eunice aphroditois & C & & & & & 2.8 \\
\hline Euphrosine capensis & $\mathrm{C}$ & 19.8 & 3.5 & 11.1 & 75.0 & 39.8 \\
\hline Golfingia capensis & $F$ & & 1.8 & & & \\
\hline Gunnarea capensis & $\mathrm{F}$ & 226.5 & & & 4.9 & \\
\hline Holothuroidea & $F$ & & 0.3 & & & \\
\hline Hydrozoa & $?$ & & & & 26.3 & 39.4 \\
\hline Kraussina rubra & $F$ & & 4.6 & & 12.3 & 8.6 \\
\hline Lepidonotus semitectus & C & 6.3 & 5.2 & 11.5 & 16.3 & 35.7 \\
\hline Lumbrinereis tetraura & $\mathrm{C}$ & & & & & 1.0 \\
\hline Lysidice natalensis & $\mathrm{C} ?$ & & 0.7 & & & \\
\hline Maera inaequipes & $?$ & 18.9 & 11.9 & 21.7 & 27.3 & 42.4 \\
\hline Marphysa sp. & 0 & & & 4.3 & & \\
\hline Megalomma quadricolatum & $\mathrm{F}$ & & & 35.6 & & \\
\hline Mesanthura catenula & $?$ & & & & & 1.3 \\
\hline Nematoda & $?$ & 1.9 & & & & \\
\hline Nereis sp. & $\mathrm{O}$ & & 0.8 & 3.4 & & \\
\hline Oligochaetae & $?$ & & 1.7 & 7.4 & & 1.8 \\
\hline Ophiothrix fragilis & $?$ & 24.2 & 26.2 & 26.5 & 64.8 & 55.2 \\
\hline Parechinus angulosus & G & & 0.5 & & & \\
\hline Patiria granifera & $\mathrm{O}$ & & & & & 10.5 \\
\hline Pherusa sp. & $\mathrm{D}$ & & & & & 66.6 \\
\hline Platyhelminthes & $?$ & & 2.3 & & & \\
\hline Polynoe erythrotaenia & $\mathrm{C}$ & & & & & 9.7 \\
\hline Porifera A & $\mathrm{F}$ & & & & 35.9 & \\
\hline Porifera B & $\mathrm{F}$ & & & & 8.0 & \\
\hline Porfera C & $F$ & & & & 2.1 & \\
\hline Sipunculida & $\mathrm{D}$ & 1.8 & 1.4 & & & 10.3 \\
\hline Syllis $\mathrm{sp}$ & C & & & & 15.7 & \\
\hline Synalpheus anisocheir & $\mathrm{C}$ & 9.7 & 3.1 & & 5.2 & 11.1 \\
\hline Temnophlias capensis & $?$ & & 6.6 & & & 114.3 \\
\hline Thais squamosa & $\mathrm{C}$ & & & 5.1 & & \\
\hline Trypanosyllis gemmulifera & 2 & 6.2 & 11.0 & & & \\
\hline Zoanthidea & $\mathrm{F}$ & & 2.7 & 12.9 & & \\
\hline
\end{tabular}

\section{DISCUSSION}

Fig. 3 depicts the trophic structure of the kelp holdfast community as reflected by the radioisotope feeding experiments described above. It is stressed that this food web is far from complete, being based on those animals that happened to occur in the experimental holdfasts and on arbitrary thresholds of radioactivity. It should also be noted that activity in the short-term experiments implies uptake onto the feeding apparatus or ingestion, but does not necessarily imply that the labelled material is absorbed into the gut of the animal.

A group of 4 taxa, including the predominant kelpbed mussel Aulacomya ater (Velimirov et al., 1977; Field et al., 1980a) took up the labelled phytoplankton culture. Although negative results are not conclusive, it is noteworthy that only very small amounts of the 

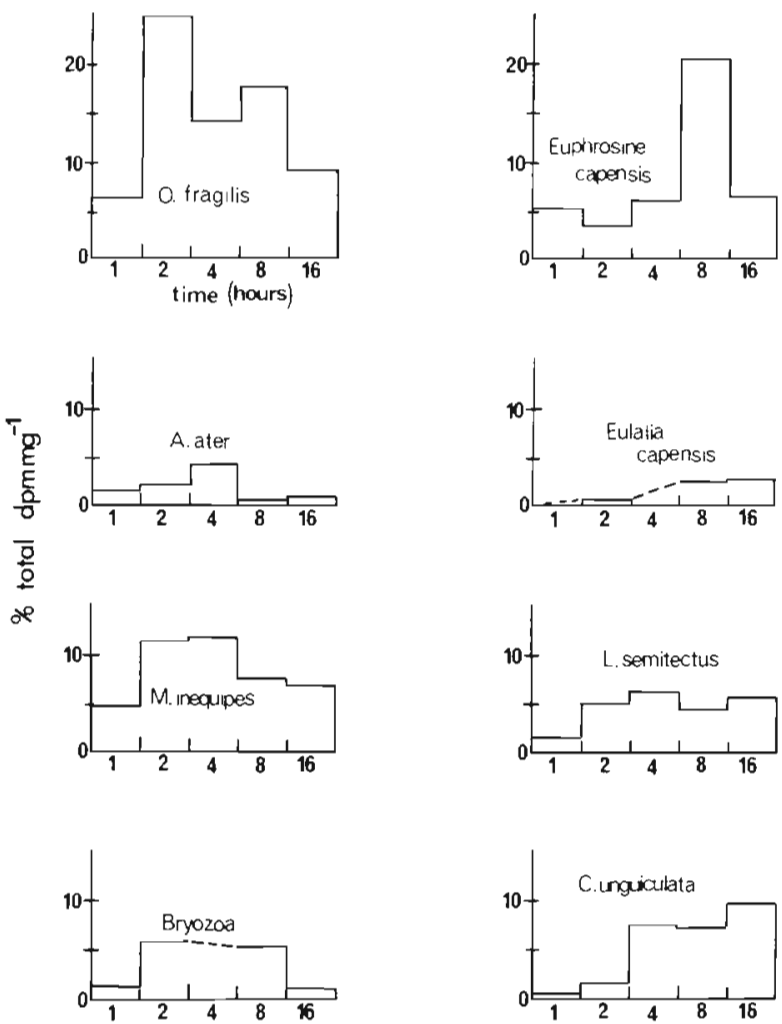

Fig. 2. Relative concentrations of radioactivity measured in each holdfast for some common species at different times after exposure of kelp holdfast microcosms to radio-labelled artificial detritus. Taxa in left hand column show most activity in shorter-duration experiments, those in right hand column tend to show greater activity in longer-duration experiments. See text for details

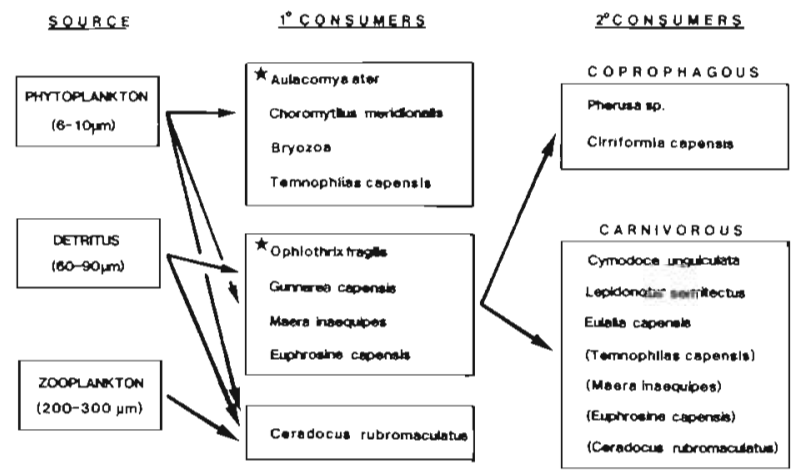

Fig. 3. Trophic structure of kelp holdfast community, based on evidence of radioisotope feeding experiments. Secondary consumers are based on detritus experiments only. Asterisks: animals dominant in kelp bed community; parentheses: omnivores that occur both as primary and secondary consumers

labelled detritus were taken up by $A$. ater in 5 separate experiments involving some 50 small specimens of the mussel which were observed to be active. It appears that small specimens of $A$. ater do not feed on the larger $(60$ to $90 \mu \mathrm{m})$ particles of detritus, although $A$. ater have been reported feeding on particles in the range 1 to $100 \mu \mathrm{m}$ (Griffiths, 1980; V. Stuart, pers. comm.).

Another group of 4 species took up both phytoplankton and detritus, suggesting that they collect food particles in the range 6 to $90 \mu \mathrm{m}$. These include the brittle star Ophiothrix fragilis, which is patchily common in South African west coast kelp beds (Velimirov et al., 1977; Field et al., 1980a).

The secondary consumers are inferred from the appearance of the ${ }^{14} \mathrm{C}$ label 8 to $16 \mathrm{~h}$ after exposure of the microcosm to suspended detritus. The tentaclefeeding polychaetes Pherusa sp. and Cirriformia capensis are unlikely to be carnivorous and are therefore listed as coprophagous, since precautions were taken to limit detritus settling to a minimum. All members of the carnivore group have biting mouthparts, supporting the classification. Several of these species also took up label in the shorter 1-h or 2-h experiments, suggesting that they fed directly on phytoplankton and detritus. These are therefore also listed as primary consumers; the results indicate that they are omnivores which probably feed individually on clumps of particles or small animals.

The results thus suggest the trophic structure of a kelp holdfast benthic community on a qualitative basis and indicate that several small animals in the community are omnivorous. The technique of using radioisotope labelled potential food in experiments of different duration was successful in revealing secondary as well as primary consumers and may have wide application in other aquatic communities that can be isolated experimentally.

Acknowledgements. We thank R. C. Newell, R. Carter, L.D.M. Whitaker and V. Stuart for help in planning and executing the experiments. Our thanks are also due to $\mathrm{S}$. Tolosana and D. Gianakouras for assisting with the manuscript. The work was supported by the South African Committee for Oceanographic Research and the Atomic Energy Board.

\section{LITERATURE CITED}

Alldredge, A. L. (1976). Discarded appendicularian houses as sources of food, surface habitats, and particulate organic matter in planktonic environments. Limnol. Oceanogr. 21 : $14-23$

Carefoot, T. (1977). Pacific seashores: a guide to intertidal ecology, J. J. Douglas, Vancouver

Day, J. H. (1967). A monograph on the Polychaeta of southern Africa, Brit. Mus. (Nat. Hist.), London

Day, J. H. (1974). A guide to marine life on South African shores, A. A. Balkema, Cape Town

Field, J, G., Griffiths, C. L., Griffiths, R. J., Jarman, N., Zoutendyk, P., Velimirov, B., Bowes, A. (1980a). Variations in structure and biomass of kelp communities along 
the south-west Cape coast. Trans. R. Soc. S. Afr. 44: $145-203$

Field, J. G., Griffiths, C. L., Linley, E. A., Carter, R. A. Zoutendyk, P. (1980b). Upwelling in a nearshore marine ecosystem and its biological implications. Estuar. coast. Shelf Sci. 11: 133-150

Gerlach, S. A., Ekstrom, D. K., Eckhardt, P. H. (1976). Filter feeding in the hermit crab Pagurus bernhardus. Oecologia (Berl.) 24: 257-265

Gilmer, R. W. (1972). Free floating mucus webs: a novel feeding adaptation for the open sea. Science, N, Y. 176: $1239-1240$

Griffiths, C. L., King, J. A. (1979). Some relationships between size, food availability and energy balance in the ribbed mussel Aulacomya ater. Mar. Biol. 51: 141-149

Griffiths, R. J. (1980). Natural food availability and assimilation in the bivalve Choromytilus meridionalis. Mar. Ecol. Prog. Ser. 3: 151-156

Hamner, W. M., Madin, L. P., Alldredge, A. L., Gilmer, R. W., Hamner, P. P. (1975). Underwater observations of gelatinous zooplankton sampling problems, feeding biology, and behaviour. Limnol. Oceanogr. 20: 907-917

Mann, K. H. (1982). Necessity of measuring fluxes. In: Mann, K. H., Platt, T., Ulanowicz, R. (eds.) Mathematical models in biological oceanography, UNESCO Monographs on oceanographic methodology, Rome

McKinley, K. R., Wetzel, R. G. (1977). Tritium oxide uptake by algae: an independent measure of phytoplankton photosynthesis. Limnol. Oceanogr. 22: 377-380

Roger, C., Grandperrin, R. (1976). Pelagic food-webs in the tropical Pacific. Limnol. Oceanogr 21: 731-735

Smith, D. F. (1982). Feeding and food-webs. In: Mann, K. H. Platt, T., Ulanowicz, R. (eds.) Mathematical models in biological oceanography, UNESCO Monographs on oceanographic methodology, Rome

Smith, D. F., Bulleid, N. C., Campbell, R., Higgins, R. W. Lowe, F., Tranter, D. J., Tranter, H. (1979). Marine foodweb analysis: an experimental study of demersal zooplankton using isotopically labelled prey species. Mar. Biol. 54: 49-59

Stuart, V., Lucas, M. I., Newell, R. C. (1981). Heterotrophic utilisation of particulate matter from the kelp Laminaria pallida. Mar. Ecol. Prog. Ser. 4: 337-348

Velimirov, B., Field, J. G., Griffiths, C. L., Zoutendyk, P. (1977). The ecology of kelp-bed communities in the Benguela upwelling system: analysis of biomass and spatial distribution. Helgoländer wiss. Meeresunters. 30: 495-518

This paper was submitted to the editor; it was accepted for printing on May 13, 1982 